\title{
Diffusion Coefficient Measurements in Lithium Ion Conductive Oxides by means of Neutron Radiography
}

\author{
Shigeomi Takai ${ }^{1}$, Yuji Kawabata ${ }^{2}$, Takao Esaka ${ }^{1}$
} Faculty of Engineering, Tottori University ${ }^{1}$, Research Reactor Institute, Kyoto University ${ }^{2}$

\section{0}

\begin{abstract}
Neutron radiography (NR) technique has been applied to the diffusion coefficient measurements of lithium ions in ion conductive solids using ${ }^{7} \mathrm{Li} /{ }^{6} \mathrm{Li}$ stable isotopes as tracer. In this article, we present the procedure of diffusion coefficient measurement by means of NR method, and reviewed the results of three types of lithium ion conductors, i.e. $\mathrm{Li}_{4 / 3} \mathrm{Ti}_{5 / 3} \mathrm{O}_{4}$, LISICON solid solutions, and perovskite-type lithium ion conductors, including analyses of diffusion mechanisms.
\end{abstract}

KEYWORDS: Neutron Radiography, Diffusion, Oxide, Lithium Ion Conductor

1. はじめに

中性子ラジオグラフィー（NR）は中性子線の透 過像から物質内部のマクロな構造や組成の分布等 を調べる手法として発展してきた[1]. 中性子の減 衰係数は電子との相互作用が主となるX線の場合 とは異なり，水素やリチウムなどの軽元素でも比 較的大きな值を示すことから，NR は材料中，と くに 2 次電池や燃料電池内部におけるこれらの元 素分布の非破壊測定法として極めて有効であると いえる[2-4]. リチウムについて見ると，その中性 子吸収断面積は同位体間でも大きく異なり，自然 存在比 $7.6 \%$ 程度の ${ }^{6} \mathrm{Li}$ は $910 \mathrm{~b}$ であるが，大多数 を占める ${ }^{7} \mathrm{Li}$ では $33 \mathrm{mb}$ と 4 析以上異なる [5]. し たがって中性子を大きく減衰する他の元素が物質 中になければ，透過強度からリチウムの同位体濃 度分布を求めることが可能である。我々は ${ }^{7} \mathrm{Li}$ か らなるリチウムイオン伝導体中で ${ }^{6} \mathrm{Li}$ 卜レーサー が拡散する様子を NR により観測し，トレーサー 拡散係数を求めてきた[6-9]. 本稿では NR を用い たリチウムの拡散係数測定の手法を概説し，これ までに行ってきたリチウムイオン伝導性酸化物の 拡散係数測定の結果を紹介寸る.

\section{2. 原理と実験手法}

前述のように中性子減衰係数がリチウムの同位 体間で大きく異なることから，同じ組成でも ${ }^{6} \mathrm{Li}$ を含む試料では中性子を吸収するためラジオグラ フィー像は白いままであるが, ${ }^{7} \mathrm{Li}$ からなる試料で は中性子を透過しフイルムを感光する（Fig.1）.

両者を貼り合わせて高温で熱処理するとリチウム 同位体は相互に拡散するため, 滑らかなグラデー

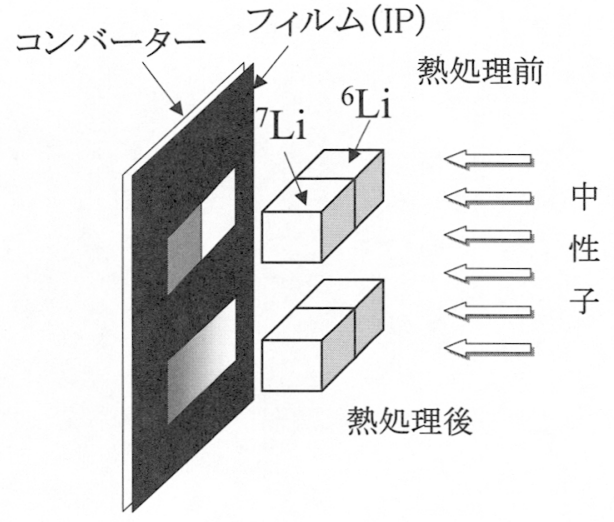

Fig.1 Schematic illustration of neutron radiography (NR) for diffusion coefficient measurements. Neutron flux is attenuated in the sample consisting of ${ }^{6} \mathrm{Li}$ to remain the NR image white, while that of ${ }^{7} \mathrm{Li}$ gives dark image even for the same composition and dimension of the samples. When a set of samples with different isotope ratio attached together have been annealed, NR image represents smooth gradation caused by ${ }^{6} \mathrm{Li} /{ }^{7} \mathrm{Li}$ interdiffusion.

ションをもつ NR 像が得られる。この同位体濃度 プロファイルを Fick の式の解でフィッティング することにより拡散係数を得る。拡散対を用いる 方法の他に ${ }^{7} \mathrm{Li}$ からなる試料端面に ${ }^{6} \mathrm{Li}$ を塗布・ア ニールしても同様の実験が可能である。これまで 試料のリチウムイオン伝導性酸化物は焼結体を使 用してきた。粒界拡散を無視できる単結晶の方が 望ましいが，様々な同位体比をもつ標準試料を含 めて数 $\mathrm{mm}$ 角の結晶をいくつも用意するのは困難 であるため，なるべく高温で焼結して粒成長させ 
(a)

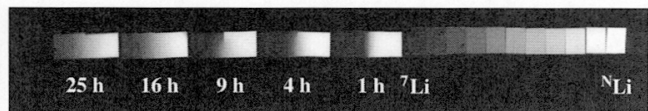

(b)

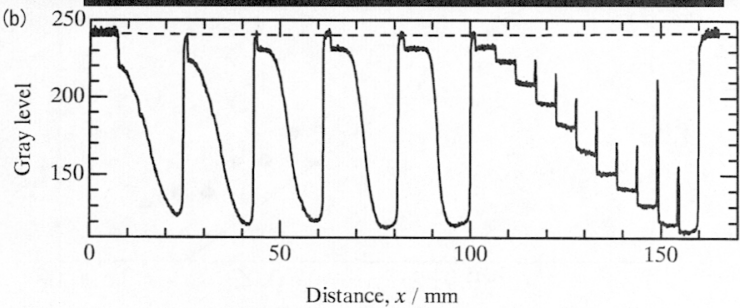

Fig.2 NR image of the diffusion couples and standard samples of $\mathrm{Li}_{4 / 3} \mathrm{Ti}_{5 / 3} \mathrm{O}_{4} .{ }^{\mathrm{N}} \mathrm{Li} /{ }^{7} \mathrm{Li}$ diffusion couples were annealed at $880^{\circ} \mathrm{C}$ for $1,4,9,16$ and 25 hours, respectively and standard sample altered the isotope ratio every $10 \%$. Numerical gray level is also given in the bottom.

粒界の影響を低減した。得られた焼結体試料はマ イクロカッターで角柱状に切断し, $9 \mu \mathrm{m}$ のダイヤ ラップ液を用いて標準試料も含めて厚さを精密に 揃えた。また拡散対を使用するときには拡散界面 での物質移動が大きな問題となるため, 拡散面に ついては研磨剤を次第に細かくしてゆき最終的に $0.25 \mu \mathrm{m}$ のダイヤモンド研磨剤で鏡面仕上げを行 った. 冷中性子を用いること，および線除去用の $\mathrm{Pb}$ 板のみを介して試料と中性子用イメージング プレート（IP）を密着することにより，分解能の 高い像を得た。

NR 実験は標準試料と拡散試料を IP 上に一列に 並べ，京大原子炉実験所 CN-3 冷中性子ガイドチ ユーブの前を IP ごと一定速度で走査することに より行った。これによりガイドチューブ内の中性 子束のばらつきにかかわらず，走查方向について は入射中性子束が一定となるようにした。

3. リチウムイオン伝導体の拡散係数の測定

リチウムイオン伝導体はリチウム固体電池やガ スセンサーの電解質材料として用いられる。 これ らの物質ではイオン伝導率がその性能を大きく支 配するため, 拡散係数の測定は基礎物性の測定と いう観点ばかりでなくセンサや電池の設計といっ た応用面からも重要となる. リチウムイオンの拡 散係数は NMR や電気化学的方法でも測定されて いるが，前者はリチウムイオンのジャンプに関す るミクロな情報を得ているだけであり, 後者は電 極での電荷の出入りしか検出しておらず, ともに 実際のリチウムイオンの分布を測定して拡散係数 を求めているのではない. とくにリチウムイオン 輸率が 1 ではない場合や, 拡散機構が明らかでは ない場合は拡散係数の見積もりは不確かになる.

このため，同位体を用いて寒際にリチウムイオン の分布状態を求め, そこから拡散係数を求める中 性子ラジオグラフィー法は非常に強力な手段と言 える. 以下これまでに行ってきた $\mathrm{Li}_{4 / 3} \mathrm{Ti}_{5 / 3} \mathrm{O}_{4}$ [6], LISICON [8]および $\mathrm{La}_{2 / 3-\mathrm{x}} \mathrm{Li}_{3 \mathrm{x}} \mathrm{TiO}_{3}$ [9]の結果につい

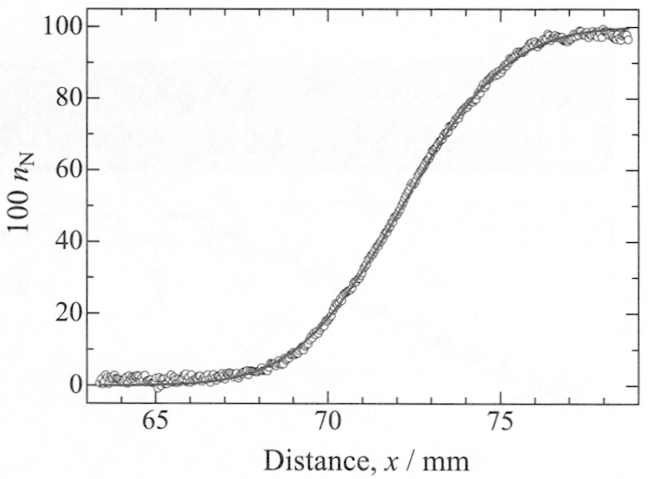

Fig.3 Isotope profile of the $\mathrm{Li}_{4 / 3} \mathrm{Ti}_{5 / 3} \mathrm{O}_{4}$ diffusion couple annealed at $880^{\circ} \mathrm{C}$ for 4 hours. The solid line was obtained by fitting assuming the solution of Fick's equation.

てそれぞれ紹介する。

\section{1. $\mathrm{Li}_{4 / 3} \mathrm{Ti}_{5 / 3} \mathrm{O}_{4}$}

$\mathrm{Li}_{4 / 3} \mathrm{Ti}_{5 / 3} \mathrm{O}_{4}$ はスピネル型構造を示し, 比較的高 温でリチウムのイオン輸率がほぼ 1 のイオン伝導 体である.Fig.2(a)に $880^{\circ} \mathrm{C} て ゙ 1 ， 4 ， 9 ， 16$ および 25 時間アニールした拡散対試料および右側に同 位体濃度較正用の標準試料の NR 像を示す。これ を数值化する（黒化度に直す）と(b)のグラフのよ うになる。標準試料では ${ }^{6} \mathrm{Li}$ (実際には ${ }^{6} \mathrm{Li} /{ }^{7} \mathrm{Li}$ が 自然存在比のもの；ここでは ${ }^{\mathrm{N}} \mathrm{Li}$ とする）の濃度 が高くなるほど低い值を示し，また拡散対試料で は，拡散アニールの時間が長くなるほど界面での 黒化度の変化は緩やかになっている。標準試料の 黑化度の同位体濃度依存性から $880^{\circ} \mathrm{C}$ で 4 時間ア ニールした試料の NR 像の黒化度を ${ }^{\mathrm{N}} \mathrm{Li}$ の濃度に 変換すると, Fig.3のプロットが得られる。これは 半無限固体を張り合わせたときの Fick の式の解,

$$
c=\left(c_{0} / 2\right)\left(1+\operatorname{erf}\left(\left(x-x_{0}\right) / 2 \sqrt{D^{*} t}\right)\right)
$$

で表すことができ, 界面の位置 $x_{0}$ と $\left(D^{*} t\right)^{1 / 2}$ をパラ メータとしてフィッティングすると，実線のよう に測定データとよく一致する。様々な拡散温度・ 拡散時間のデータに対してフィッティングを行っ てそれぞれ $\left(D^{*} t\right)^{1 / 2}$ を求め, 実際の拡散時間の平方 根に対してプロットすると Fig.4 のようになり，

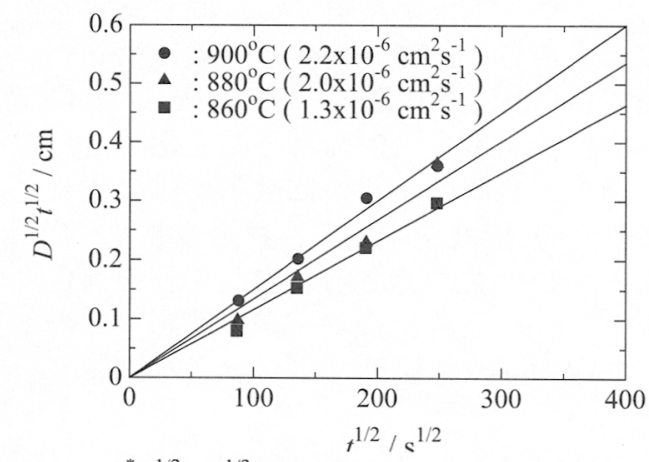

Fig.4 $\left(D^{*} t\right)^{1 / 2}-t^{1 / 2}$ plots of $\mathrm{Li}_{4 / 3} \mathrm{Ti}_{5 / 3} \mathrm{O}_{4}$ annealed at $900^{\circ}$ (-), $880^{\circ}(\mathbf{A})$,and $860^{\circ} \mathrm{C}$ ( $)$. [7] 


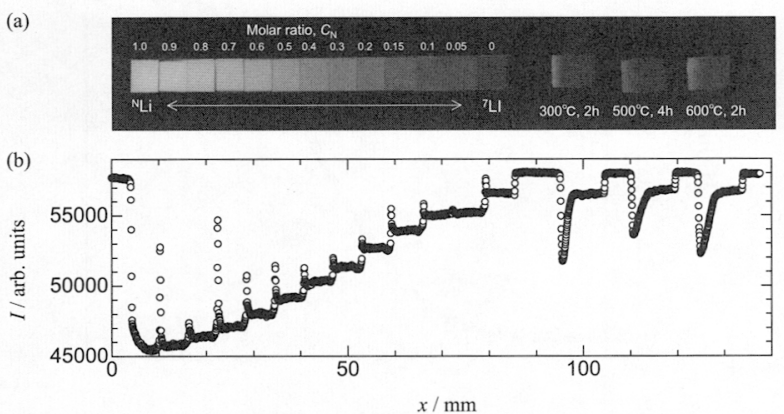

Fig.5 NR image of the standard and diffusion samples of LISICON. Diffusion samples were annealed at $300^{\circ} \mathrm{C}$ for $2 \mathrm{~h}, 500^{\circ} \mathrm{C}$ for $4 \mathrm{~h}$, and $600^{\circ} \mathrm{C}$ for $2 \mathrm{~h}$, respectively after smeared ${ }^{6} \mathrm{LiNO}_{3}$ saturated solution.

傾きは $D^{1 / 2}$ に相当する. 少しばらついてはいるも のの, それでも拡散温度が高温になるに従って傾 きは大きくなり, 拡散係数が増大してゆく様子が わかる。拡散対を用いる方法は高温実験に限定さ れ測定温度領域は狭いものの, アレニウスプロッ トから求めた活性化エネルギーは電気伝導率から 求めた值とほぼ一致しており, 高い確度を有して いるといえる.

\subsection{LISICON}

次に $300{ }^{\circ} \mathrm{C}$ 程度でも高いリチウムイオン伝導 性を示す酸化物として知られている LISICON の 拡散係数測定の結果について示す. $\mathrm{Li}_{4} \mathrm{GeO}_{4}$ と $\mathrm{Zn}_{2} \mathrm{GeO}_{4}$ の混晶系の中でも $\gamma_{\mathrm{II}}$-リン酸リチウム型 構造を示す物質は高いリチウムイオン伝導性を示 し，とくに $\mathrm{Li}_{2+2 \mathrm{x}} \mathrm{Zn}_{1-\mathrm{x}} \mathrm{GeO}_{4}(\mathrm{x}=0.75)$ の組成のも のはリチウムイオン伝導性が最も高く LISICON と呼ばれている.これらについては多くの研究が 行われているが, 拡散係数の測定はほとんど行わ れていない，そこでNR 実験により拡散係数を測 定するとともに, より低 $\mathrm{Li}$ 組成のもの（ $\mathrm{x}=0.5$; ZRA (zinc rich analogue)) と比較して, とくに拡 散機構の相違について調べてみることにした。 $300^{\circ} \mathrm{C}$ 付近では前述のような拡散対を用いた方法 では界面での Li の移動が物質内での拡散に追い つかないため, ${ }^{7} \mathrm{Li}$ からなる角柱状試料の端面に ${ }^{6} \mathrm{LiNO}_{3}$ の飽和水溶液を塗布し, 所定の温度でアニ ールした。また NR 実験終了後, 同じ試料を繰り 返しアニールして長時間の拡散実験に供した.

実験で得られた NR 像の一例を Fig.5 (a) に示す. 左側は同位体濃度を $10 \%$ こことに変化させた標準 試料の像で，右側の 3 個の拡散試料はいずれも左 側面に ${ }^{6} \mathrm{LiNO}_{3}$ 溶液を塗布し, 表記の温度・時間だ けアニールしたものである。 またこれを黒化度に なおすと，(b)のようになる。表面薄層からのトレ 一サー拡散の同位体濃度プロファイルは

$$
c(x)=\left(M / \sqrt{\pi D^{*} t}\right) \exp \left(-x^{2} /\left(4 D^{*} t\right)\right)
$$

であるから，濃度の対数を表面からの距離の 2 乗 に対してプロットすると傾きは - $1 / 4 D^{*} t$ となる。

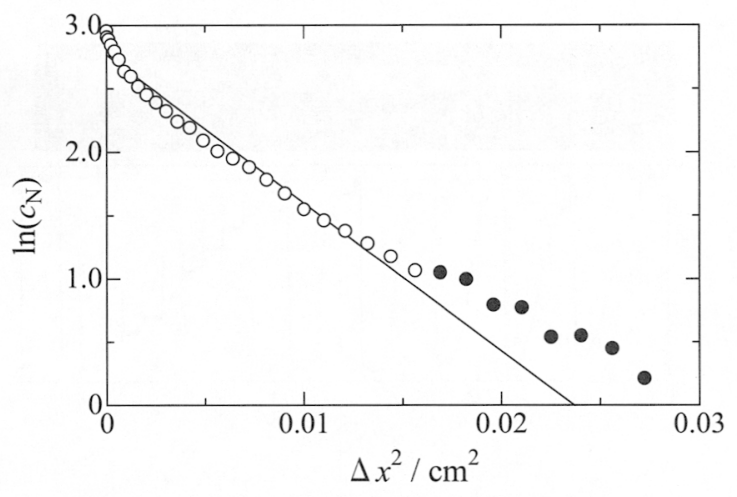

Fig.6 Logarithmic plots of the isotope concentration against square of the distance from the diffusion surface.

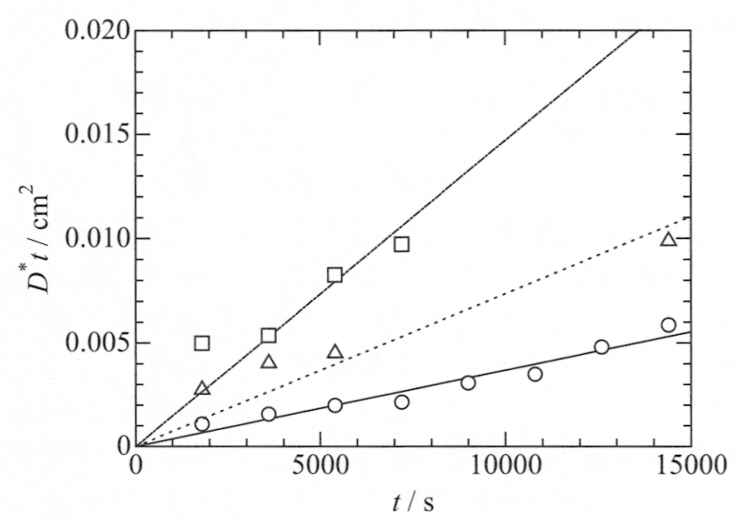

Fig.7 $D^{*} t-t$ plots of LISICON diffusion samples annealed at $300^{\circ}(\bigcirc), 400^{\circ}(\triangle)$ and $500^{\circ} \mathrm{C}(\square)$. [7]

Fig.6 に $300^{\circ} \mathrm{C}$ で 2 時間アニールした LISICON 拡 散試料の $\ln c-x^{2}$ プロットを示す。白でプロット した領域はよく直線に載り，この領域での傾きか ら $D^{*} t$ を求めた。 Fig.7 に LISICON について各温 度でそれぞれ 30 分おきに合計 2 4 時間熱処理を 行って得られた $D^{*} t$ を拡散時間 $\mathrm{t}$ に対してプロッ トした。 この傾きから求めた拡散係数のアレニウ スプロットを Fig. 8 に示す. $500^{\circ} \mathrm{C}$ の ZRA のデー 夕を無視すると活性化エネルギーは LISICON $(O)$ と $\mathrm{ZRA}(\triangle)$ で類似した值を示した。

また, 電気伝導率 から Nernst-Einstein の関係 $D_{\sigma}=k_{B} T \sigma /\left(n Z^{2} e^{2}\right)$ を用いて導出した拡散係数も 黒いシンボルで示した。ここで $n$ および $Z$ は可動 イオンの密度および電荷であり, $e$ は電気素量で ある. $n$ については酸素 4 面体中の $\mathrm{Li}$ は動かない ものとし，格子間サイトの Liイオンのみを用いた. トレーサー拡散係数と電気伝導率から求めた拡散 係数の比 $\left(D^{*} / D_{\sigma}\right)$ は Haven 比 $\left(H_{\mathrm{R}}\right)$ と呼ばれ, 上記の Nernst-Einstein の定義式では相関係数 $f$ が その大部分を担っているものと考えられる[10].

Fig.9 L LISICON と ZRA の $H_{\mathrm{R}}$ を示したが, 両者 は近い值であった。基本的に相関係数はイオンの 導電経路によって決まるので, Fig.9 から LISICON と ZRA で拡散パスは大きな違いがないものと考 えられた. LISICON にのみ存在寸る Li の占有少 


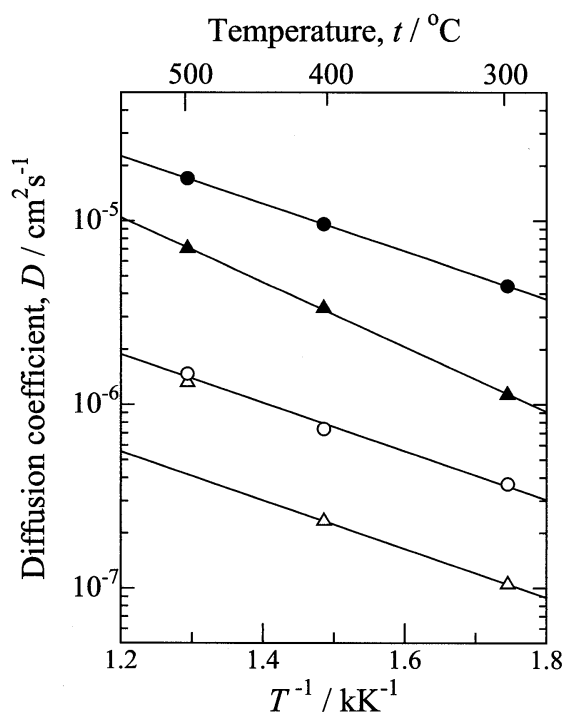

Fig.8 Arrhenius plots of diffusion coefficients of LISICON and ZRA. Open symbols: tracer diffusion coefficients obtained from NR method, closed symbols: calculated ones from conductivity assuming Nernst-Einstein's relation. $\mathrm{O}, \boldsymbol{\bullet}$ : LISICON, and $\triangle, \boldsymbol{\Delta}$ : ZRA. [8]

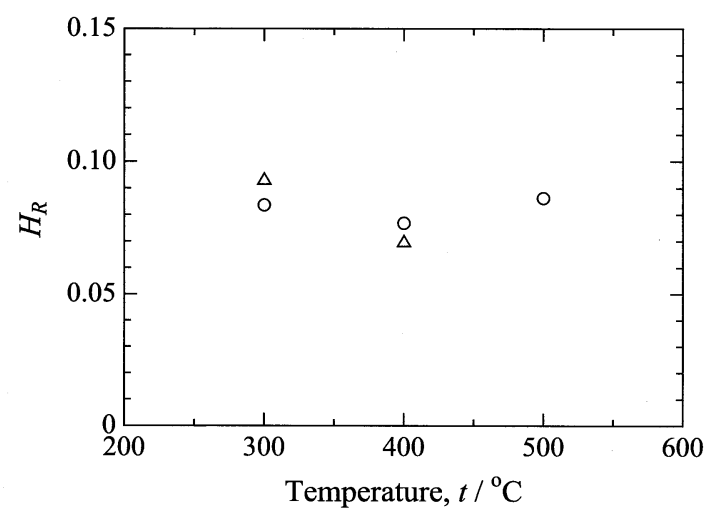

Fig.9 Haven ratio of LISICON $(O)$ and ZRA $(\triangle)$. [8]

イトも報告されてはいるものの[11], 拡散係数の 活性化エネルギーがほぼ一致することも含めて，

ZRA に比べて LISICON が高いリチウムイオン伝 導性を示すことは新たな導電パスの形成に起因す るものではなく，易動度の向上によるものと予想 できた。

\section{3. ペロブスカイト型リチウムイオン伝導体}

$\mathrm{La}_{2 / 3-\mathrm{x}} \mathrm{Li}_{3 \mathrm{x}} \mathrm{TiO}_{3}$ はペロブスカイト型構造を示すリ チウムイオン伝導体で, 室温付近でも $10^{-3} \mathrm{~S} \mathrm{~cm}^{-1}$ 程度の高いイオン伝導率を示すことから数多くの 研究がなされている.この系では A サイトに La, $\mathrm{Li}$ および空孔が分布し, $\mathrm{x}$ の值は Li の入っていな い 0 から A サイトが完全に埋まってしまう 0.166 まで変化し, イオン伝導率は $\mathrm{x}=0.1$ 付近で極大值 を示す. Liイオンは隣の A サイトが空孔のときに のみ移動できるという基本的なモデルに従えば中 間組成で高いイオン伝導率を示すのは, 低 $\mathrm{Li}$ 組成 では可動 $\mathrm{Li} イ$ イの数が少なく, また高 $\mathrm{Li}$ 領域 では A サイトが詰まってしまい Li イオンが移動 しにくくなるためであると理解されている.この

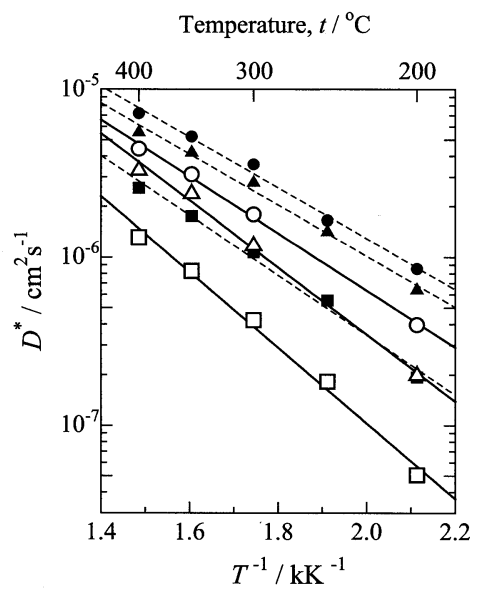

Fig.10 Arrhenius plots of diffusion coefficients of $\mathrm{La}_{2 / 3-\mathrm{x}} \mathrm{Li}_{3 \mathrm{x}} \mathrm{TiO}_{3} . \quad \mathrm{O}: \mathrm{x}=0.066, \triangle: \mathrm{x}=0.116$ and $\square: \mathrm{x}=$ 0.166 . The corresponding closed symbols denote the diffusion coefficients obtained by Nenst-Einstein's relation. [9]

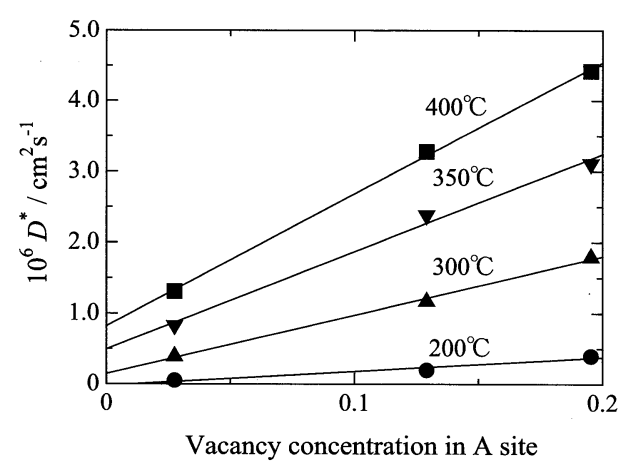

Fig.11 Diffusion coefficients plotted against the vacancy concentration in $\mathrm{A}$-site of $\mathrm{La}_{2 / 3-\mathrm{x}} \mathrm{Li}_{3 \mathrm{x}} \mathrm{TiO}_{3}$. [9]

モデルに従えば，x の值が低いほどリチウムの拡 散係数は大きくなるはずである。そこで前項の LISICON と同様の手法でこの系の拡散係数を測 定した。

NR の測定手順は繰り返しになるので省略し, 結果のアレニウスプロットを Fig.10 に示す.トレ 一サー拡散係数は白いプロットのように $\mathrm{x}$ の值が 増加するに従って低下する傾向を示し，A サイト が詰まるに従って Li イオンは動きにくくなると いう仮定と整合性を示したＩCP による組成分析

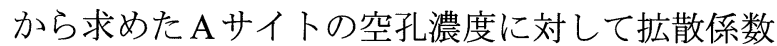
をプロットすると（Fig.11），高温では切片の值は 大きいものの, $200^{\circ} \mathrm{C}$ 程度になると拡散係数は $\mathrm{A}$ サイト空孔濃度にほぼ比例する傾向を示した。隣 接する A サイトが空孔である確率は直接 A サイト の空孔濃度に相当するので, 長距離の拡散に伴う パーコレーション等を無視すれば，この結果は妥 当なものといえる。また高温での切片の増大は熱 平衡による空孔生成のために, 室温で化学分析に より求めた以上の空孔を含んでいることによるの かもしれない. Fig.10 には電気伝導率から求めた 拡散係数も黒いプロットで示しており，これら 2 種類の拡散係数から Haven 比を求めたのが Fig.12 


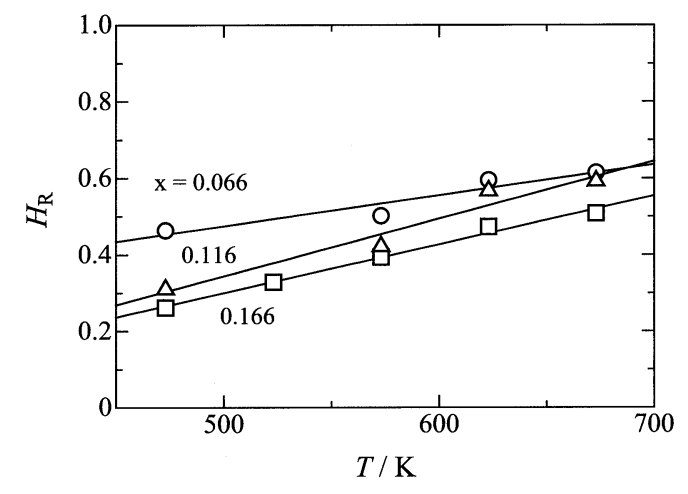

Fig.12 Measured Haven ratio of $\mathrm{La}_{2 / 3-\mathrm{x}} \mathrm{Li}_{3 \mathrm{x}} \mathrm{TiO}_{3}$. $\mathrm{O}: \mathrm{x}=0.066, \triangle \mathrm{x}=0.116, \square: \mathrm{x}=0.166$.

である.このペロブスカイト型構造を立方晶で近 似すると A サイト副格子は単純立方格子となり, そのときの理想的な Haven 比は 0.65 となる. Fig.12 を見ると, 可動イオンの運動に対してイオン間の 相互作用が相対的に小さくなる高温ほどこの值に 近づく傾向を示している. 低 Li 組成の試料ではさ らに高温になると 0.65 を超えようとしているが, これは任意の空孔の周囲にほとんど空孔が存在し ない条件での理想的な值が 0.65 で，これに比べて 極めて空孔濃度が高い組成では格子間拡散機構

（理想的には $f=1 ）$ の特徴を帯びてくるためであ ると考えられる.したがって $\mathrm{x}=0.166$ のように空 孔が少ない組成の試料で最終的に 0.65 に収束する ものと考えられる.

実際には $\mathrm{La}$ が A サイト副格子中の導電パス中 に介在物として存在すること，立方晶ではなく少 し歪んだ正方晶や斜方晶であること，またこれに 伴い空孔や La の分布が均一ではないこと, さら には Li の局在化する位置が A サイトの中心では ないという報告もあることから，上記の議論は峳 密には成り立たないかもしれないが，基本的なモ デルから大きくずれているわけではないものと考 えられる.さらに精密な実験を行うことができれ ば，今回単純化した因子も含めて導電機構を議論 できるものと考えられた。

\section{4. まとめと今後の展望}

本稿ではこれまでに我々の研究グループで行っ てきた，NR を用いた拡散係数測定について述べ てきた. 同位体濃度分布から拡散係数を求める本 手法は，電子伝導や他のイオン伝導あるいは電極 反応の見積もりにかかわらず確かに Li の拡散の みを観測しており，得られたデータは高い確度を 有していると言える。また電気伝導率から求めた データも相補的に用いることにより, Haven 比の 議論のようにマクロな同位体分布からミクロな拡 散機構を論じることができる点は特筆すべきであ る.もちろん拡散係数の絶対值のみから拡散機構 を予想することはできないが，精度の高い拡散係 数測定の結果は詳細な構造解析等から導かれた拡 散機構のモデルを判断する際に満たすべき絶対的 な条件を与える.
これまでの実験は標準試料を含めて多くの試料 を用意し，試料厚さを揃えるために角柱状に加工 する必要があったため, 多結晶（焼結体）試料を 用いて行ってきた. 透過中性子に対して検出器の 感度のリニアリティーが確保できれば, Fig.6の解 析で傾きしか使わないことから標準試料を省略で きるので, 数 $\mathrm{mm}$ 角の単結晶試料のみを用いて拡 散実験ができるのではないかと思われる．単結晶 では粒界拡散を無視でき，結晶方位依存性も調べ ることができる。また最近短寿命核 ${ }^{8} \mathrm{Li}$ を用いた 拡散係数測定も考案されており [12], NR では測定 しにくい中性子減衰係数の大きな元素を含む材料 やバルク試料が作れない場合には有効と思われる. しかし安定同位体を使用する NR は測定の空間分 解能に合わせて拡散時間スケールを任意に設定で きる点で依然として大きなメリットをもつものと 考えられる.

最後になるが，これまでの実験は主として京大 原子炉で行ってきたが，06 年度から中性子ビーム が休止しており，国内での実験は主に原研で行う ことになる。また京大原子炉でのビーム再開時で も, 低出力運転となることが予定されているので, これに合わせて検出方法や実験手法も変わってく るのではないかと思われる．使用できる中性子源 や in situ 測定など目的によって実験方法や周辺機 器等も異なってくるが, NR は水素やリチウムイ オン等の固体内の拡散に関する情報を与える有力 な手法として確立してゆくものと期待される.

\section{参考文献}

[1] たとえば，小林久夫 他，非破壊検査，53(2) (2004)「中性子ラジオグラフィを用いた非破壊検 査(NRT)技術」特集号.

[2] M. Kamata, T. Esaka, S. Fujine, K. Yoneda, K. Kanda, J. Power Sources, 68 (1997) 459.

[3] M. Lanz, E. Lehmann, R. Imhof, I. Exnar, P. Novak, 101 (2001) 177.

[4] R.J. Bellows, M.Y. Lin, M. Arif, A.K. Thompson, D. Jacobson, J. Electrochem. Soc., 146 (1999) 1099.

[5] V.F. Sears, in: E. Prince (Ed.), International Tables for Crystallography, vol. C Kluwer Academic Publishing, Dordrecht, pp. 440-450, 1999.

[6] S. Takai, M. Kamata, S. Fujine, K. Yoneda, K. Kanda, T. Esaka, Solid State Ionics, 123 (1999) 165.

[7] S. Takai, M. Kamata, S. Fujine, K. Yoneda, K. Kanda and T. Esaka, Neutron Radiography (6), Proceedings of the 6th World Conference on Neutron Radiography, pp. 479-484, (2001).

[8] S. Takai, K. Kurihara, K. Yoneda, S. Fujine, Y. Kawabata, T. Esaka, Solid State Ionics, 171 (2004) 107.

[9] S. Takai, T. Mandai, Y. Kawabata and T. Esaka, Solid State Ionics, 176 (2005) 2227.

[10] P.G. Shewmon, Diffusion in Solids, McGrawHill, NewYork, 1963. 
[11] I. Abrahams, P.G. Bruce, A.R. West, W.I.F. David, J. Solid State Chem., 75 (1988) 390.

[12] S.C. Jeong, I. Katayama, H. Kawakami, Y. Watanabe, H. Ishiyama, H. Miyatake, M. Sataka, S. Okayasu, H. Sugai, S. Ichikawa, K. Nishio, T. Nakanoya, N. Ishikawa, Y. Chimi, T. Hashimoto, M. Yahagi, K. Takada, B.C. Kim, M. Watanabe, A. Iwase, T. Hashimoto, T. Ishikawa, Nucl. Inst. Met. Phys. Res. B 230 (2005) 596. 